\title{
MODEL KOMUNIKASI ANTARBUDAYA ETNIS MADURA DAN ETNIS DAYAK DI DESA BASAWANG KABUPATEN KOTAWARINGIN
}

\author{
Khadijah, \\ IAIN Palangka Raya, Indonesia \\ Az_zahra60@ymail.com
}

Received :

; Accepted :

; Published :

\begin{abstract}
:
This study tries to explore on "How the intercultural communication of Madurese ethnic and Dayak ethnic in Basawang Village, East Kotawaringin Regency, Central Kalimantan Province after the ethnic war at 2001?”. . Researchers assume that this research is interesting because after the ethnic war at 2001 in the Village of Basawang Ethnic Dayak with Ethnic Madurese living together, in a harmonious and conducive state, there had even been an inter-ethnic language exchange.

This phenomenon is being uncovered by using qualitative research method with symbolic interaction model, by studying the behavior and human interaction which can be ifferentiated by symbol and its meaning. Three data collecting techniques undertaken are: observation, depth interview and literature review.

The result indicates that as a theory of intercultural communication model according to William B. Ludykunst and Young Yun Kim, this can be seen from the perceptions of the two ethnicities. The result indicates that mutual adaption has occurred between Madurese ethnic as new comers and Dayak Ethnic as native people. The attitude of mutual respect between newcomer ethnic and native ethnic enables them to do their own cultural activity. The Madurese ethnic use Madurese, Dayak or Malay language with Banjar dialect in order to talk with Dayak ethnic. The relation between these two ethnics has continued without obstacle as both ethnics have accepted each other as it is.
\end{abstract}

Keywords: Intercultural Communication, Madurese ethnic, Dayak ethnic

Indonesia merupakan sebuah negara-bangsa (nation-state) yang sangat majemuk dilihat dari berbagai dimensi. Salah satu dimensi menonjol dari kemajemukan itu adalah keragaman Etnis atau suku bangsa. Sampai saat ini ada berbagai pendapat mengenai jumlah suku bangsa yang ada di Indonesia. Atas dasar jumlah bahasa daerah, maka Esser, Berg dan St. Takdir Alisjahbana memperkirakan 200 sampai 250 suku bangsa Indonesia. Sedangkan menurut Koentjaradiningrat ada 195 suku bangsa di Indonesia (Soerjono Soekanto, 1983: 48). Kemajemukan bangsa Indonesia ini telah melahirkan perpaduan yang sangat indah dalam berbagai bentuk mozaik budaya.

Budaya dan masyarakat ibarat dua sisi mata uang logam yang merupakan satu kesatuan yang tidak dapat dipisahkan antara satu sama lain. Budaya tanpa masyarakat itu tidak mungkin, begitu juga sebaliknya masyarakat tanpa budaya itu juga tidak mungkin. Dalam suatu sistem sosial masyarakat maka manusia tidak bisa lepas dari struktur-struktur 
yang ada dalam masyarakat itu sendiri, di mana itu semua sudah diakui oleh masyarakat sejak lama yang terdiri dari bermacam-macam agama, suku, kepercayaan, dan lain-lain. Terkait dengan perbedaan lokasi geografis yang menjadikan manusia berbangsa-bangsa dan bersuku-suku Allah SWT mewajibkan bagi mereka semua untuk saling mengenal dan bekerja sama dalam takwa kepada Allah, sebagaimana firman-Nya dalam alqur'an surah Hujurat [49]:13.

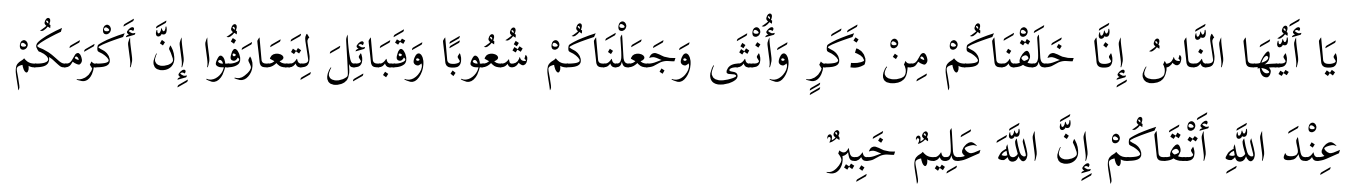

Artinya:

"Hai manusia, Sesungguhnya Kami menciptakan kamu dari seorang laki-laki dan seorang perempuan dan menjadikan kamu berbangsa - bangsa dan bersuku-suku supaya kamu saling kenal-mengenal. Sesungguhnya orang yang paling mulia diantara kamu disisi Allah ialah orang yang paling taqwa diantara kamu. Sesungguhnya Allah Maha mengetahui lagi Maha Mengenal."

Ayat tersebut mengungkapkan sesungguhnya Allah telah memerintahkan kepada semua umat manusia untuk "saling mengenal", dalam arti tidak perlu ada prasangka sosial, prasangka antarEtnis, prasangka antarkelompok, intinya bahwa kita harus saling mengasihi. Sejak alqur'an diturunkan kita sudah diberikan nilai normatif. Bagaimana seharusnya (das sollen), hubungan antarbudaya, kelompok Etnis, bangsa dilakukan, dan bagaimana menjembatani semua ini. (M. Hashem,1993:3)

Komunikasi antarbudaya (intercultural communication) yang baik adalah jembatan bagi keberaganaman tersebut. Komunikasi antarbudaya pada dasarnya mengkaji bagaimana budaya berpengaruh terhadap akti-vitas komunikasi: apa makna pesan verbal dan nonverbal menurut budaya-budaya bersangkutan, apa yang layak dikomunikasikan, bagaimana cara mengkomunikasikannya (verbal dan nonverbal) dan kapan mengkomunikasikannya (Dedy Mulyana, 2000:xi).

Masalah kesukubangsaan merupakan kajian yang sangat penting karena sebagian besar dari negara-negara di dunia ini bersifat multiEtnis. Di antara sekitar 175 negara anggota Perserika-tan Bangsa-Bangsa, hanya 12 negara yang pen-duduknya kurang lebih homogen. Karena itu masalah kesukubangsaan merupakan masalah global (Koentjaraningrat, 1993:3).

Berbagai suku, agama, adat istiadat dan budaya dapat hidup berdampingan dan memiliki ruang negosiasi yang sangat tinggi dalam kehidupan sehari-hari. Namun, 
keraguan yang terajut indah itu kini terkoyak dan tercabik oleh sikap permusuhan yang tumbuh dari akar primordialisme sempit kesukuan, agama dan golongan. Peristiwa konflik atau kerusuhan yang terjadi di beberapa daerah, baik dalam eskalasi kecil maupun besar dengan membawa korban amat besar baik jiwa maupun harta benda, sehingga menghancurkan sendi-sendi kemanusiaan dan kebangsaan kita. Salah satu peristiwa konflik antar suku di Indonesia ialah konflik antar suku yang terjadi di Sampit pada tahun 2001, konflik ini telah menelan banyak korban jiwa dan kerugian harta benda. Kerusuhan ini juga meluas sampai Ibu Kota Propinsi Kalimantan Tengah (Imam Tholkhah,2002:1-2).

Masyarakat Dayak tidak memiliki sifat suka berperang maupun memusuhi Etnis lain yang ada di daerah Kalimantan. Begitu juga dengan Etnis Madura sebagai pendatang sebenarnya sudah sejak lama antara Etnis Dayak dengan Etnis Madura hidup berdampingan antara satu sama lain, dalam keadaan yang harmonis dan kondusif. Berdasarkan observasi peneliti bahkan ada sebagian Etnis Madura yang sudah terlahir dan mati di daerah Desa Basawang Kabupaten Kotawaringin Timur Provinsi Kalimantan Tengah serta tidak sedikit dari Etnis Madura yang mengikat hubungan batin melalui perkawinan dengan masyarakat Dayak, dan yang menarik lagi antar kedua Etnis ini sudah terjadi pertukaran bahasa. Sebagian Etnis Dayak sudah bisa menggunakan bahasa Madura begitu juga sebaliknya.

Tanpa komunikasi yang baik, komunikasi tatap muka, maupun komunikasi dengan menggunakan media massa penyebaran informasi, terutama informasi kebudayaan akan sulit untuk diperoleh, keadaan seperti ini akan berakibat kurang baik terhadap keranekaragaman budaya yang dimiliki serta akan lebih mempermudah munculnya perselisihan paham karena kekurangpahaman yang akhirnya mengarah kepada konflik. Untuk itu pembahasan komunikasi sangat diperlukan guna kelancaran proses interaksi dengan orang lain.

Hubungan komunikasi dengan budaya itu bersifat timbal balik dalam banyak hal, dimana keduanya saling mempengaruhi, dari apa yang dibicarakan, bagaimana membicarakannya dan apa yang dilihat turut membentuk serta menetukan, begitu juga pada gilirannya apa yang dilihat dan apa yang dipikirkan itu dipengaruhi oleh budaya yang akhirnya budaya akan hidup tanpa komunikasi dan komunikasi tidak akan hidup tanpa budaya.

Dengan adanya komunikasi yang baik antara satu pihak dengan pihak yang lainnya maka kesamaan arti untuk mencapai suatu tujuan bersama akan mudah tercapai. Keadaan demikianlah yang menunjukkan berhasilnya suatu proses komunikasi yang berlangsung antara kedua belah pihak. 
Penelitian ini dilakukan untuk melihat bagaimana komunikasi antar budaya pada Etnis Madura dan Etnis Dayak di Desa Basawang Kabupaten Kotawaringin Timur Provinsi Kalimantan Tengah pasca kerusuhan tahun 2001. Penelitian ini dianggap menarik oleh peneliti karena pasca kerusuhan Tahun 2001 di Desa Basawang Etnis Dayak dengan Etnis Madura hidup berdampingan antara satu sama lain, dalam keadaan yang harmonis dan kondusif, bahkan telah terjadi pertukaran Bahasa antar Etnis.

Adapun perumusan masalah dalam penelitian ini adalah bagaimana model komunikasi antarbudaya antara Etnis Madura dan Etnis Dayak di Desa Basawang Kabupaten Kotawaringin Timur Provinsi Kalimantan Tengah?

Penelitian ini bertujuan untuk mengetahui model komunikasi antarbudaya antara Etnis Madura dan Etnis Dayak di Desa Basawang Kabupaten Kotawaringin Timur Provinsi Kalimantan Tengah.

Komunikasi antarbudaya (intercultural communication) adalah proses pertukaran pikiran dan makna antara orang-orang berbeda budaya. Ketika komunikasi terjadi antara orang-orang berbeda bangsa, kelompok ras, atau komunitas bahasa, komunikasi tersebut disebut komunika-si antarbudaya.

Komunikasi antar Etnis juga merupakan bagian dari komunikasi antarbudaya, sebagaimana komunikasi antarras, komunikasi antarag-ama dan komunikasi antargender (antara pria dan wanita). Dengan kata lain komunikasi antarbudaya lebih luas daripada bidang-bidang komunikasi yang disebut belakangan. Komunikasi antar Etnis merupakan komunikasi antarbudaya, tetapi komunikasi antarbudaya belum tentu merupakan komunikasi antar Etnis (Dedy Mulyana,1993: xi-xii).

Scharm mengemukakan empat syarat diperlukan individu untuk berkomunikasi antarbudaya secara efektif yaitu: pertama, menghormati anggota budaya lain sebagai manusia; kedua, menghormati budaya lain apa adanya, bukan sebagaimana yang kita kehendaki; ketiga, menghormati hak anggota budaya yang lain untuk bertindak berbeda dari cara kita bertindak; keempat, komunikator lintas budaya yang kompeten harus belajar menyenangi hidup bersama orang dari budaya yang lain.

\section{METODE}

Penelitian ini menggunakan metode kualitatif. Pendekatan kualitatif berguna untuk menggambarkan suatu realita dan kondisi sosial dalam masyarakat. Menurut Nasution (Sudjarwo, 2001: 25) pendekatan kualitatif merupakan pendekatan yang berdasarkan pada kenyataan lapangan dan apa yang dialami responden. Untuk mengungkap fenomena 
komunikasi etnis Madura dengan etnis Dayak, penulis menggunakan metode penelitian kualitatif dengan pendekatan interaksi simbolik.

Inti dari teori interaksi simbolik adalah teori tentang 'diri' (self) dari George Herbert Mead, seperti juga Cooley, menganggap bahwa konsep diri adalah suatu proses yang berasal dari interaksi sosial individu dengan orang lain (Mulyana, 2001: 73). Dengan teori ini penulis dapat memahami bagaimana persepsi interpersonal mempengaruhi komunikasi interpersonal. Teknik pengumpulan data dalam penelitian ini dilakukan dengan tiga cara, yaitu: (1) observasi melalui pendekatan peran serta, (2) wawancara mendalam, dan (3) penggunaan dokumen.

Pada penelitian ini penulis melakukan pengamatan langsung terhadap masyarakat etnis Madura serta masyarakat sekitar. Melalui pendekatan peran serta ini penulis melakukan percakapan langsung yang tidak terencana atau non formal. Percakapan dengan informan tersebut kemudian menjadi data pendukung yang akan penulis pelajari dalam menganalisis data.

Teknik pengumpulan data dengan wawancara mendalam, memberikan keleluasaan bagi informan untuk memberi pandangan-pandangan secara bebas (Koentjaraningrat, 1989:30). Wawancara yang penulis gunakan adalah wawancara yang mendalam atau wawancara tak berstruktur. Wawancara tak berstruktur mirip dengan percakapan informal (Mulyana, 2001: 181). Wawancara jenis ini dilakukan karena bersifat luwes, susunan pertanyaan atau kata-kata dapat diubah saat wawancara dilaksanakan, disesuaikan dengan kebutuhan, dan kondisi informan yang dihadapi.

Analisis data penelitian ini dilaksanakan bersamaan waktunya dengan tahap pengumpulan data di lapangan, bahkan analisis data dilakukan sejak awal dan sepanjang proses penelitian berlangsung. Penarikan kesimpulan dilakukan berdasarkan data yang dihimpun diolah melalui proses reduksi, sajian data dan verikasi.

\section{HASIL}




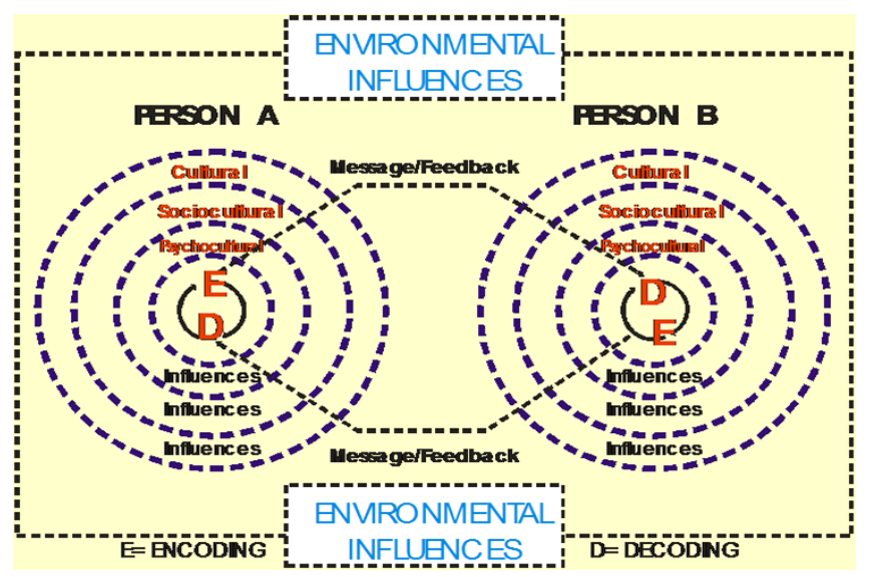

Hasil temuan pada penelitian ini yaitu sebagaimana Teori model komunikasi antarbudaya menurut William B.Gudykunst dan Young Yun Kim, komunikasi yang dilakukan oleh Etnis Dayak dan Etnis Madura yang berasal dari budaya yang berlainan, dimana masing-masing individu berperan sebagai pengirim sekaligus juga penerima pesan. Dengan begitu, pesan yang disampaikan seseorang merupakan umpan balik untuk lawan bicaranya, sehingga terjadi penyandian serta penyandian balik pesan (perbaharuan pesan). Hal ini dapat dilihat dari persepsi kedua Etnis tersebut.

\section{PEMBAHASAN}

\section{Persepsi Etnis Madura terhadap Etnis Dayak}

Ada sebagian Etnis Madura yang masih menaruh curiga terhadap tindakan dan kegiatan yang dilakukan oleh Etnis Dayak dalam upaya untuk menggusur Etnis Madura dari Desa Basawang. Sebagian Etnis Madura merasa was-was dan berjagajaga terhadap segala kemungkinan yang terjadi apabila terjadi konflik lagi yaitu kerusuhan yang melibatkan Etnis Madura dan Etnis Dayak, sehingga sebagian Etnis Madura lebih mempererat hubungan antar Etnis Madura sendiri untuk menangkal pengaruh dari Etnis Dayak.

Sebelum kerusuhan yang terjadi tahun 2001 Etnis Madura berpandangan orang Dayak lemah, penakut dan sebagainya, hal tersebut juga akan mempengaruhi cara komunikasi yang dilakukan kedua Etnis ini. Namun pasca kerusuhan tersebut Etnis Madura berpandangan bahwa pada dasarnya, masyarakat Etnis Dayak memiliki sifat lembut dan mudah mengalah, namun ketika berhadapan dengan orang yang memiliki tempramen yang begitu keras serta dendam tersendiri yang terakumulasi secara maksimal, maka lama-kelamaan bisa memunculkan sentiment tersendiri yang bertolak belakang dengan sifat asli masyarakat Etnis Dayak. 
Etnis Dayak memiliki prinsip Huma Betang yaitu bersama atau bersatu dalam keberagaman. Sebagaimana yang diungkapkan Suwarno, Nilai yang menonjol dalam kehidupan di rumah betang adalah nilai kebersamaan (komunalisme) di antara para warga yang menghuninya, terlepas dari perbedaan-perbedaan yang mereka miliki (Suwarno, 2017;89). Nilai kebersamaan ini yang kemudian muncul menjadi budaya toleransi untuk saling menghargai antar etnis. Seseorang yang hidup di masyarakat yang baru ia kenal mempunyai tantangan yang beragam baik secara bahasa, sikap masyarakat, sistem kepercayaan serta budaya yang sangat berbeda dengan lingkungan sebelumnya (Hana Silvana, 2013:102). Untuk beradaptasi dan dapat hidup di masyarakat yang beragam etnis dan budaya para komunitas masyarakat dituntut untuk menghargai budaya antar warga masyarakat. Adaptasi budaya merupakan proses jangka panjang dalam rangka penyesuaian diri dimana tahapan akhir dalam proses ini adalah tercapainya perasaan nyaman dalam lingkungan yang baru (Kim dalam Martin dan Nakayama, 2000: 277).

Etnis Madura berpandangan masyarakat Etnis Dayak mudah menerima dan menyesuaikan diri dengan suku-suku di lingkungannya. Sebagian besar Etnis Dayak di Desa Basawang sudah mahir berbahasa Madura, begitu pula sebaliknya. Hal ini terjadi akibat dari komunikasi yang dilakukan baik dalam pergaulan sebagai teman maupun keluarga, karena sebagian Etnis Dayak ada yang menikah dengan Etnis Madura. Hal ini dimungkinkan karena sosialisasi sewaktu masa kanak-kanak (fase bermain) yang dialami sering terjadi sentuhan antara etnis Madura dengan etnis Dayak. Bagi orang-orang yang memiliki kemampuan seperti tersebut di atas, hambatan dalam berkomunikasi antar etnis nyaris tidak ada. Orang-orang seperti ini dapat menjadi jembatan hubungan antar etnis.

Kemudahan dalam berkomunikasi dikarenakan masyarakat etnis Madura dan Dayak di Desa Basawang telah memenuhi syarat yang diperlukan dalam melakukan komunikasi antar-budaya seperti: 1) adanya sikap menghormati anggota budaya lain sebagai manusia; 2) adan-ya sikap menghormati budaya lain sebagaima-na adanya, dan bukan sebagaimana yang kita kehendaki; 3) adanya sikap menghormati hak anggota budaya yang lain untuk bertindak berbeda dari cara kita bertindak; 4) komunika-tor lintas budaya yang kompeten harus belajar menyenangi hidup bersama orang dari budaya yang lain (Rumondor dalam Anugrah dan Kres-nowiati, 2008).

\section{Persepsi Etnis Dayak terhadap Etnis Madura}


Etnis Dayak berpandangan bahwa orang Madura keras, bertemparamen tinggi, mudah marah dan sebagainya akan berpengaruh pada bentuk komunikasi yang akan dibangun dengan orang madura tersebut. Warga Madura di Desa Basawang dianggap terlalu gampang menyelesaikan selisih paham dengan menggunakan senjata tajam. Warga Madura membawa senjata tajam untuk menjaga diri dan bila perlu untuk membela kehormatan. Tetapi, itulah yang dipandang mendorong mudahnya warga Madura melakukan tindak kekerasan.

Persepsi Etnis Dayak terhadap Etnis Madura pasca kerusuhan tahun 2001 bahwa orang Madura sebagai Etnis pendatang dan minoritas di Desa Basawang sudah dapat membaur, dan mengurangi sifat tempramennya, bahkan saat ini kepercayaan masyarakat Etnis Dayak terhadap Etnis Madura sangat tingi, pada pemilu tahun 2018 lalu masyarakat Etnis Dayak mempercayakan jabatan pimpinan tertinggi di Desa yaitu Kepala Desa kepada Etnis Madura.

Berdasarkan observasi dan wawancara terhadap kedua suku bangsa yang berbeda ini peneliti melihat adanya keterkaitan antara integrasi sikap dan perilaku budaya dengan variabel-variabel, seperti lamanya menetap di suatu daerah, pola pemukiman, jenis pekerjaan, dan frekuensi interaksi dengan ingroup maupun outgroup-nya.

Efek atau umpan balik dengan adanya komunikasi antarbudaya Etnis Dayak dan Etnis Madura di Basawang adalah integrasi sikap dan perilaku budaya terlihat dari kesediaan beberapa informan menyesuaikan diri dengan suku-suku yang ada di lingkungannya, misalnya dengan mempelajari bahasa, membiasakan diri dengan masakan dari ingroup maupun outgroup, mengadopsi nilai-nilai budaya dari suku-suku setempat. Hal ini juga mengisyaratkan bahwa antara Etnis Dayak dan Etnis Madura terdapat rasa saling tenggang rasa dengan tidak memperbesar perbedaan tetapi berusaha untuk menyelesaikan setiap permasalahan dengan pertemuan atau dialog. Etnis Madura mempunyai itikad untuk berusaha membangun dialog dengan etnis Dayak apabila ada perbedaan pendapat, dengan jalan melakukan pertemuan dan diskusi dengan tokoh-tokoh masyarakat yang mewakili Etnis Dayak untuk menyelesaikan segala permasalahan dengan cara musyawarah untuk mufakat. Baik Etnis Dayak dan Etnis Madura sama-sama menghindari kekerasan apabila terjadi suatu masalah dalam hubungan antar etnis. Hal ini juga menunjukkan bahwa sebenarnya Etnis Dayak dan Madura tidak suka permusuhan dan kekerasan apabila terjadi beda pendapat antar etnis. Keduanya berusaha untuk menempuh jalan perdamaian dengan jalan mencari titik temu apa yang menjadi masalah dan berusaha 
untuk menyelesaikan permasalahan itu dengan jalan damai yaitu dengan melakukan dialog dan pertemuan dengan tokoh masing-masing.

Berdasarkan uraian di atas dapat diketahui bahwa usaha yang dilakukan yaitu membicarakan apa yang menjadi permasalahan tersebut, setelah mendapatkan solusi, tokoh masyarakat menyampaikan kepada masing masing sukunya. Etnis Melayu dan Madura mengadakan pertemuan yang intinya membicarakan dan membahas apa yang menjadi masalah yang terjadi diantara hubungan budaya diantara keduanya. Pertemuan tersebut dihadiri oleh tokoh- tokoh masyarakat dari etnis masing-masing yang berdiskusi dengan tidak saling menyalahkan diantara keduanya. Tokoh-tokoh tersebut berupaya untuk menemukan akar permasalahan atau sengketa yang terjadi dengan mengedepankan musyawarah untuk mufakat dan tidak saling menyalahkan. Setelah terjadi kesepakatan diantara tokoh-tokoh masyarakat yang berkumpul dan berdiskusi tersebut, maka hasil dari pertemuan tersebut disampaikan kepada kelompok-kelompok atau etnis masingmasing.

Suasana yang meliputi tempat dan waktu yang digunakan oleh Etnis Melayu dan Madura dalam berkomunikasi antarbudaya adalah di Masjid atau di rumah salah satu tokoh masyarakat pada saat perayaan hari besar keagamaan umat Islam. Di dalam perayaan Etnis Dayak mengundang Etnis Madura untuk ikut bersama merayakan hari besar Islam yang sudah menjadi adat istiadat masyarakat di Desa Basawang. Etnis Madura juga sering diundang untuk menghadiri acara-acara keagamaan yang dilaksanakan oleh Etnis Dayak seperti Idul Fitri, Idul Adha, Isra' Mi'raj dan Maulid Nabi Muhammad SAW.

Kedua etnis tersebut berusaha untuk mencari kesamaan yaitu beragama Islam dan menjalankan perintah sesuai dengan ajaran Islam, sehingga dengan adaya kesamaan tersebut diharapkan akan tercipta rasa persaudaraan diantara keduanya. Di dalam ajaran Islam juga disebutkan bahwa sesama muslim adalah saudara sehingga tokoh-tokoh masyarakat etnis Madura dan Dayak berusaha untuk menyatukan Etnis tersebut karena pada dasarnya mereka adalah saudara.

Budaya menentukan dan membentuk perilaku, nilai dan bahkan pikiran suatu kelompok masyarakat. Hal ini juga berlaku di dalam etnis Madura dan etnis Dayak. Masing-masing etnis masih memiliki rasa primordialisme masing- masing kelompok budaya terhadap budayanya. Untuk beradaptasi terhadap suatu budaya tertentu bukanlah merupakan suatu pekerjaan yang mudah, karena budaya dibekalkan kepada manusia dilahirkan ke dunia yang tentunya melalui proses pembelajaran oleh tempat tinggal yang mempunyai sifat dan ciri-ciri tersendiri. Sehingga apabila seseorang pergi ke suatu daerah 
yang memiliki budaya yang berbeda dengan tempat asalnya, maka mau tidak mau harus berusaha untuk beradaptasi dengan memahami budaya di lokasi yang baru tersebut.

Hasil penelitian juga memperkuat teori etnosentrisme yang menjelaskan bahwa budaya seseorang lebih unggul dibandingkan budaya orang lain. Terkadang sifat etnosentrisme penting untuk mengeratkan hubungan dalam suatu masyarakat. Seperti budaya, etnosentrisme juga biasanya dipelajari secara tidak sadar. Misalnya, sekolah yang hanya mengajarkan sejarah, geografi, sastra, bahasa, serta pemerintahan negara sendiri dan mengecualikan yang lainnya sedang melakukan tindakan etnosentrisme. Hal ini juga berlaku di etnis Dayak dan etnis Madura yang tinggal di Desa Basawang yang beranggapan bahwa etnis masing-masing lebih unggul dibandingkan etnis yang lain.

Komunikasi antarbudaya yang melibatkan Etnis Dayak dan Etnis Madura tidak bisa terlepas dari hakikat proses komunikasi antarbudaya yang menyatakan bahwa komunikasi ini tidak bisa dipandang sekedar sebagai sebuah kegiatan yang menghubungkan manusia dalam keadaan pasif, tetapi komunikasi harus dipandang sebagai proses yang menghubungkan manusia melalui sekumpulan tindakan yang terus menerus diperbaharui. Hal ini sesuai dengan hasil observasi yang telah dilakukan peneliti di lokasi penelitian yang menemukan fakta bahwa komunikasi antarbudaya Etnis Dayak dan Etnis Madura merupakan proses yang menghubungkan manusia melalui sekumpulan tindakan yang terus menerus diperbaharui, sebagaimana Teori model komunikasi antarbudaya menurut William B.Gudykunst dan Young Yun Kim.

\section{KESIMPULAN}

Pasca Kerusuhan antar etnis tahun 2019 Etnis Dayak dan Etnis Madura samasama menghindari kekerasan, apabila terjadi suatu masalah dalam hubungan antar etnis. Hal ini juga menunjukkan bahwa sebenarnya Etnis Dayak dan Madura tidak suka permusuhan dan kekerasan apabila terjadi beda pendapat antar etnis. Keduanya berusaha untuk menempuh jalan perdamaian dengan jalan mencari titik temu apa yang menjadi masalah dan berusaha untuk menyelesaikan permasalahan itu dengan jalan damai yaitu dengan melakukan dialog dan pertemuan dengan tokoh masing-masing.

Integritas sikap yang baik dari Etnis Madura melahirkan kepercayaan masyarakat Etnis Dayak terhadap Etnis Madura, hal ini terlihat pada pemilu Kepala Desa Basawang Tahun 2018, dimana Kepala Desa terpilih adalah dari Etnis Madura.

Kerukunan antar kedua Etnis dapat dilihat dari kegiatan saling mengundang antara Etnis Dayak dan Etnis Madura dalam merayakan hari besar keagamaan. Apabila Etnis 
Dayak mengadakan suatu perayaan hari besar keagamaan, maka akan mengundang Etnis Madura untuk menghadiri dan ikut berpartisipasi, begitu juga sebaliknya apabila Etnis Madura merayakan hari besar keagamaan juga akan mengundang pihak Etnis Dayak.

Faktor penghambat dalam komunikasi antarbudaya antara Etnis Dayak dan Etnis Madura di Desa Basawang adalah masyarakat Madura kurang bisa membaur dengan masyarakat Melayu. Kurangnya pengetahuan Etnis Madura terhadap tradisi ataupun kebiasaan yang dilakukan masyarakat Etnis Dayak, Etnis Madura kurang mampu menguasai bahasa Etnis Dayak, rendahnya keinginan Etnis Madura untuk mengikuti adat dan tradisi masyarakat Etnis Dayak, serta frekuensi interaksi Etnis Madura dengan masyarakat Etnis Dayak tergolong rendah.

\section{DAFTAR PUSTAKA}

Hashem, M. (1993), Islam dan Masalah Ras, Jakarta: Lentera.

J.Moleoeng,Lexy. (2007), Metodologi penelitian kualitatif, Bandung: Remaja Rosdakarya. Kriyantono,Rachmat. (2012), Public Relations \& Crisis Management, Jakarta: Kencana. Liliweri, Alo. (2007), Dasar-Dasar Komunikasi Antarbudaya, Yogyakarta:Pustaka Pelajar Offset.

Mulyana, D. (2000), Ilmu Komunikasi suatu pengantar. Bandung: Remaja Rosdakarya.

Martin, N. Judith, dan Nakayama, K.T. (2000), Intercultural Communication in Contexts, New York: Mc. Graw Hill.

Rakhmat,Jalaluddin. (1999), Psikologi Komunikasi, Bandung: Remaja Rusdakarya.

Rumondor, A. H. (2005). Komunikasi antarbu-daya. Jakarta: Pusat Penerbitan Universitas Terbuka.

Soekanto,Soerjono.(1983), Teori Sosiologi tentang Struktur Masyarakat, Jakarta:Rajawali. Tholkhah,Imam, dkk. (ed) (2002), Konflik Sosial Bernuansa Agama di Indonesia, t.tp: Puslitbang Kehidupan Beragama.

Samovar, Larry A, Porter, Richad E, Mcdaniel, Edwin R.. (2010), Komunikasi Lintas Budaya, Salemba Hunanika, Jakarta.

Lingua (2017), Budaya Huma Betang Masyarakat Dayak Kalimantan Tengah dalam Globalisasi: Telaah Konstruksi Sosial, 14 (01),89-102.

http://www.library.ohiou.edu/indopubs/2001/02/26/0009.html (Online:Kamis, 11 Februari 2016)

Departemen Agama RI, (2009), al-Qur'an dan Terjemahnya, Jakarta: SYGMA Axamedia. 